\title{
A Regulatory Approach to Diversifying Commercial Television Entertainment
}

Television-the most pervasive source of entertainment in American society ${ }^{1}$-has been aptly criticized as "a vast wasteland." 2 Broadcast television ${ }^{3}$ has been subjected to a variety of critiques-political, social, and ideological. ${ }^{4}$ The underlying theme of those critiques is the lack of diversity in television programming. Critics contend that, instead of addressing controversial social issues, television offers only inoffensive entertainment that extols sponsors' materialistic values. ${ }^{5}$ They accuse television of recycling cultural stereotypes, thereby conveying an image of American society that aggravates the complacency of the majority

1. See, e.g., Callum, What Viewers Love/Hate about Television, TV Gurde, May 12, 1979, at 6, 10 (average television usage per household over six hours per day); Biggest spenders still make TV primary medium, Broadcasting, Aug. 28, 1978, at 31 (88\% of all households view television daily); cf. Gerbner \& Gross, Living with Television: The Yiolence Profile, 26 J. CoM. 173, 176 (1976) ("With its virtually unlimited access from cradle to grave, television both precedes reading and, increasingly, preempts it.")

This Note addresses television entertainment. Entertainment programs, by any measurement, dominate the medium. See G. Comstock, S. Chaffee, N. Katzman, M. MicCombs, \& D. Roberts, Television and Human Behavior 22-24 (1978) (regular network prime-time schedule "is exclusively entertainment"; only about $12 \%$ of total schedule is non-entertainment) [hereinafter cited as G. Comstock]; cf. THE GEorgetown Law Journal, Media and the First Amendmenr in a Free SocietY 74-75 (1973) (television is most influential as entertainment medium) [hereinafter cited as MEDIA AND THE FIRST Amendment].

2. N. Minow, Equal Time 52 (1964).

3. This Note addresses only "broadcast" television entertainment, which can be received by operative television sets without the benefit of decoding devices or the payment of any fees. "Pay-as-you-go" home entertainment, upon which charges are assessed on a per-program or subscription basis, does not present the economic and constitutional problems that plague "free" television. Though the new media are now technologically viable, there is still a dearth of software (programs) by which to measure their true potential. See pp. 714-15 infra; cf. O'Connor, Today-"Original Fare Is at a Premium," N.Y. Times, July 22, $1979, \S 2$, at 1 , col. 3 (critic finds "standard television has been expanded and made slightly more permissive" in cable programs).

4. E.g., J. Mander, Four Arguments for the Elimination of Television (1978) (cataloguing harmful psychological effects and sociological dangers of television viewing); F. Mankiewicz \& J. Swerdlow, Remote Control: Television and the Manipulation of AMERICAN Life (1978) (critical examination of television's influence and ideas).

5. See, e.g., E. Barnouw, The Sponsor: Notes on a Modern Potentate 115 (1978) (entertainment shows mirror consumption ethic); cf. D. Halberstam, The Powers That BE 151 (1979) (quoting Edward R. Murrow's 1958 speech attacking network programs for " "decadence, escapism, and insulation from the realities of the world in which we live" "). 
and frustrates the aspirations of minority groups. ${ }^{6}$ Above all, critics complain that television suffers from a monotonous sameness, relying on repetitive formats and imitative themes. ${ }^{7}$

This Note contends that network entertainment programming contravenes the regulatory principles established by the Federal Communications Commission (FCC). The Note first establishes that the structure and economics of the broadcast industry frustrate programming diversity. It then argues that there is a public interest in diversity and contends that current regulatory policy infringes broadcasters' rights while failing to promote diverse entertainment. The Note examines a variety of proposals for regulatory reform and concludes by suggesting economic regulation designed to modify the industry's business practices and thus to generate programming diversity.

\section{The Economic Structure of the Broadcast Industry}

The lack of diversity in television programming stems directly from the economic structure of the broadcast industry. The pattern of program distribution, the standard practices of program production, and the strategy of network competition all contribute to television's uniformity. The economic forces of television are so strong that it is doubtful whether current FCC regulations have any measurable effect in diversifying entertainment shows and schedules.

\section{A. Economics of National Distribution}

The structure of the television industry is determined by the FCC's broadcast-frequency allocation policy. ${ }^{8}$ This policy is a deliberately

6. See U.S. Comm'n on Civil Rights, Window Dressing on the Set: An Update 7-22 (1979) (racial and sexual stereotypes in television dramas present unrealistic portrait of society).

7. This complaint is frequently reiterated by regular reviewers assigned to cover and criticize standard television fare. See, e.g., Mackenzie, Review: Flying High, TV Guide, Dec. 16, 1978, at 1 (describing “dejja-va-voom"); O'Connor, TV: 'The Immigrants,' Another "Formula" Series, N.Y. Times, Nov. 20, 1978, \$ C, at 30, col. I ("The formula is already rigid."). Success begets imitation in competing network shows, as in the simultaneous introduction of three network college-fraternity comedies, all inspired by the film $A$ nimal House. See Davidson, Send in the clones, TV Gunde, Mar. 24, 1979, at 33. Similarly, "spinoffs" move familiar characters from successful series into new shows of their own. Furthermore, television entertainment programming is always constricted by limited formats. See MacKenzie, Review: Why Don't We Talk about Television? TV GuIDE, Apr. 28,1979 , at 48 (criticizing "near-saturation of the tube with fantasy, featherweight romance, cozy comedy").

8. One of the FCC's duties is to assign frequencies and control each licensee's transmission so as to minimize interference caused by overlapping signals. See 47 U.S.C. $\S \S 303(c)$, (f), 307(b), 308(b) (1976). 
chosen plan that precludes the existence of a fourth permanent network by preventing it from reaching the number of homes necessary to generate advertising revenues commensurate with the other three. ${ }^{9}$ In implementing a policy of "localism" in frequency assignments, the FCC followed an express policy favoring a larger number of scattered local stations rather than more numerous regional viewing options. ${ }^{10}$ Although that policy grants at least one station to nearly every community, it precludes the establishment of alternative systems that could increase the number of channels available to most viewers. ${ }^{11}$ As a result, a fourth network, which would be able to reach no more than sixty percent of the national audience that receives the three existing networks, ${ }^{12}$ would be a second-class competitor. ${ }^{13}$

Unfortunately, the thirty-year-old preference for local television service $^{14}$ has failed to foster locally responsive, diverse program service; ${ }^{15}$ because the costs of originating local entertainment are prohibi-

9. See Crandall, The Economic Effect of Television-Network Program "Ownership," 14 J.L. \& Econ. 385, 393 (1971) (three-network market attributable to FCC allocation of broadcast spectrum); Robinson, The Federal Communications Commission: An Essay on Regulatory Watchdogs, 64 VA. L. REv. 169, 260 (1978) (limited number of local channels is cause of industry's oligopolistic structure).

10. See Amendment of $\$ 3.606$ of the Commission's Rules and Regulations, 1 RAD. REG. (P\&.F) (Vol. 1, pt. 3) 91:601, 91:624 (1952) (Sixth Report and Order) (rejecting allocation plan that would sustain fourth network because of advantages that derive from local stations responsive to local needs).

11. At least two alternative systems of frequency allocation that are technically feasible would sustain additional competitors and break up the current network oligopoly. One, the system of powerful regional transmitters initially rejected by the FCC, see note 10 supra, "would have been more profitable and less costly to the economy than the present system of local stations. And viewers would have six rather than three networks to choose among." R. Noll, M. Peck, \& J. McGowan, Economic Aspects of Television Regulation 117 (1973) [hereinafter cited as R. NoLL]. The other alternative, a system of local UHF transmitters that has only been made possible by relatively new technology, would allow for a proliferation of networks with competing programs. Miller, Should VHF Be Abolished? American Film, Feb. 1979, at 46.

12. Holsendolph, F.C.C. Staff Calls Agency Powerless Against TV, N.Y. Times, Oct. 17, 1979, § C, at 26, col. 5; cf. Owen, Structural Approaches to the Problem of Television Network Economic Dominance, 1979 Duke L.J. 191, 213-14 (only about one-third of population can receive four or more VHF stations).

13. Assuming perfect competition in the markets open to it, a fourth network could theoretically capture a quarter of each local audience. But on a national basis, the new competitor would only have one-quarter of $60 \%$, while the three major networks would each have one-third of the $85 \%$ left over. In addition to that disparity, a network reaching only $60 \%$ of the audience might have to sell its advertising time at a discount from the other networks, since many national sponsors would find it more efficient to have their message carried simultaneously in every market.

14. The roots of the local service doctrine stretch back to the earliest years of radio regulation. See Great Lakes Broadcasting Co., 3 F.R.C. Annual Rep. 32, 34, modified on other grounds, 37 F.2d 993 (D.C. Cir.), cert. dismissed, 281 U.S. 706 (1930).

15. See Arkansas, Louisiana, and Mississippi 1973 Renewals, 42 F.C.C.2d 3, 33 (1973) (Johnson, Comm'r, dissenting) ("local network affiliates pay little attention to local pro- 
tive, ${ }^{10}$ individual stations obtain most of their programs from national distributors. ${ }^{17}$ The strongest broadcasters in each market carry the network "feed" throughout most or all of the day. ${ }^{18}$ Independent broadcasters aggravate network dominance by relying on syndicated reruns of network material for much of their programming. ${ }^{19}$ Consequently, network shows dominate the medium's entertainment from coast to coast.

Regional frequency assignments might have allowed the coexistence of as many as six networks operating with equal access to a national audience. ${ }^{20}$ With more competitors carving the national audience into correspondingly smaller shares, there would have been an opportunity to present diversified material. ${ }^{21}$ Under the present system, competitive networks divide the audience into three roughly equal shares. ${ }^{22}$ Specialinterest programs are economically unappealing not because they lose money ${ }^{23}$ but because they do not match the inflated profits that are

gramming"); Cox \& Johnson, Broadcasting in America and the FCC's License Renewal Process: An Ohlahoma Case Study, 14 F.C.C.2d 1, 12 (1968) ("local service is largely a myth").

16. See B. Owen, J. Beebe, \& W. Manning, Television Economics 19 (1974) (local production unaffordable because cost per viewer would exceed likely advertising revenue per viewer) [hereinafter cited as Television Economics]; Schofield, Don't Look for the Home-town Touch, TV Guide, Apr. 14, 1979, at 39 (station executive contends most local outlets incapable of originating programs).

17. R. Noll, supra note 11, at 108-09.

18. See G. Comstock, supra note 1 , at $22(90 \%$ of commercial stations affiliated with network; networks provide two-thirds of their programming); B. OwEN, Economics AND FreEdom of EXPREssion 121 (1975) (network affiliation most profitable choice available to local stations).

19. See Television Economics, supra note 16, at 32-34 (syndication reliance on secondrun network series increasing at expense of original non-network programs).

20. See R. Noll, supra note 11, at 116 (regionalism "would make reception of at least six VHF signals teclmically feasible for all homes in the country"); B. OWEN, supra note 18 , at 121 (had localism not been objective, regional system could have produced half-dozen or more national networks).

21. The economists who reached this conclusion looked to the ratings of well-received but less popular shows and concluded that a six-network system would be able to generate appreciably more diversity than "a three-network system in which each network can achieve one third of the audience by mass programming." $R$. NolL, supra note 11, at 52-53. Logically, diversification should result if programmers were able to aim at the special interests of discrete audiences that, though unable to satisfy the $30 \%$ standard of mass-audience programming, could readily meet the one-sixth requirement of a six-network system.

22. In order to accomplish this objective, each network has to present equally "popular" programs. Although network executives disparage the idea that "quality"-a purely subjective variable- "diminishes in direct proportion to popularity," $A s$ We See It, TV GuIDE, Dec. 16, 1978, at A-6 (quoting ABC Television President Frederick Pierce), the monotony of network television undoubtedly stems from the limited numbers of "popular" program formats, situations, and characters.

23. See L. Brown, Keeping Your Eye on Television 26 (1979) ("even the shows that get inadequate viewing . . . will make a profit"). 
possible when the normal share of the audience is thirty percent. ${ }^{24}$ Under a system of regional frequency assignments, competition would have generated diversity simply because programmers would have been routinely tailoring their shows for smaller audiences. ${ }^{25}$

\section{B. Network Production Practices}

Although less popular shows can generate a positive cash-flow, the three networks maximize profits by a policy that uses thirty percent of the viewing audience as a benchmark; if a prime-time entertainment program attracts less than thirty percent, it is discontinued. ${ }^{20}$ No direct economic transaction is available to smaller broadcast audiences to induce broadcasters to offer specialty programs. ${ }^{2 \pi}$ Because advertisers are willing to pay premiums to place their messages on shows with high ratings, ${ }^{28}$ it is economically unappealing for networks to carry programs that do not win a maximum audience-share during each broadcast hour. ${ }^{29}$ Ratings are also compounded over the course of the

24. See pp. 698-99 infra. There is an additional disincentive because uninterested viewers do not switch off television, but instead defect to a competing network; thus, special-interest programs contribute inflated profits to competitors. L. Brown, supra note 23 , at 26.

25. See R. NoLt, supra note 11 , at $52-53$ (network special-interest programming draws 15 to $20 \%$ of audience; a system of five or six networks is required to ensure audience for specialty programs comparable with single network's routine share of mass audience).

26. L. Brown, Televi\$ion: The Business Behind the Box 33 (1971). Thirty percent indicates that a show is holding its own nationally against competition that includes the other networks, public television, and local independents. The economic rewards of massaudience parity are too high to permit specialty programs to survive in a time-slot where much greater profits could be earned. See Harmetz, CBS Moves "Paper Chase" in Effort to Raise Ratings, N.Y. Times, Jan. 16, 1979, § C, at 7 , col. 2.

One of the assumptions of the six-network model discussed above is that while one of the six networks might score a rare bonanza by successfully capturing $30 \%$ of the audience, the benchmark of routine program viability would sink to around $15 \%$. Thirty-share mass-audience programs would become as rare as sixty-share programs are observed to be in the present system, in which the competitors appear to be matched evenly over the long run.

27. Television Economics, supra note 16 , at 5 .

28. F. MANKIEwicz \& J. SwERDLow, supra note 4, at 217-18.

29. The profit-differential can be quite dramatic. It has been estimated that each additional percentage point of a network's share in the prime-time evening hours generates thirty million dollars in additional advertising revenues over the course of the season. Brown, Joy and Profits Accrue to ABC and Its Ratings Lead, N.Y. Times, Jan. 4, 1979 , $\S \mathrm{C}$, at 19 , col. I. Thus, prime-time schedules are frequently revised in order to undercut a rival's promising new shows or to make room for a new series by trimming failing programs. See Gates, $A$ Season of Brawls, Blunders and Bonanzas, TV Guide, Aug. 11,1979 , at 4.

A.C. Nielsen Company, the networks' national ratings scorekeeper, compiles weekly ratings of all network shows. The "rating" represents the percentage of all available sets tuned to a show, while the "share" is the percentage of all the sets-in-use tuned to a show. The rating, not the share, is used in billing network advertisers, who generally pay at an agreed upon cost-per-thousand viewers. See TElevision Economics, supra note 16, at 4. Thus, network revenues are commensurate with ratings, while the share indicates a particular show's competitive strength. 
season, and the networks' competitive standings are rewarded or disciplined by both affiliated broadcasters ${ }^{30}$ and private investors. ${ }^{31}$

The unrelenting competition to maximize audience shares militates against both diversified and innovative programs. ${ }^{32}$ Networks avoid risk by presenting shows based primarily on predicted mass-audience appeal. ${ }^{33}$ Artistic license is constrained by writers' contracts under which the network or production company may drop the project-or just the writer-at any stage of development if the work deviates from familiar programming norms. ${ }^{34}$ The editorial and artistic personnel involved in most program production therefore avoid risk by resorting to themes and conventions that have already proved popular and will be familiar to test audiences..$^{35}$ In addition, the tacitly understood needs of sponsors interfere with editorial freedom and require simplified program content; ${ }^{36}$ writers and producers routinely suppress the

30. See Brown, ABC-TV Reaches Affiliate Parity with Its Rivals, N.Y. Times, July 31, 1979 , $\S \mathrm{C}$, at 15 , col. 3 (ABC has traded on recent programming success to add affiliates and expand audience); Brown, NBC Slruts Its Peacock for Affiliates, N.Y. Times, May 15, $1979, \S \mathrm{C}$, at 7 , col. 4 (NBC attempting to stem affiliate defections by increasing payments to affiliates for carrying network programs).

31. Cf. D. Halberstam, supra note 5, at 253 (James Aubrey was unassailable programming chief at CBS because "no matter what questions his professional conduct raised, how terrible the shows, the profits always rose, the stock always went up"); Brown, $T V$ Producers Say Ratings War Has Hurt Quality of Programs, N.Y. Times, Jan. 15, 1979, $\S \mathrm{C}$, at 20, col. 1 (producer claims "television had changed in 10 years 'from a program business to a ratings business, because the networks' stock prices have taken to rising and falling with the ratings' ").

32. See E. BARNouw, supra note 5, at 113 (executives say personal preferences move them in other directions but professional duty is to mass preferences).

33. Batteries of tests have been developed to predict audience response to a concept, story, or finished show, and the results of such tests help the networks create new shows and modify current ones. See Bergreen, The Viewer Does Have Clout, TV Guide, Nov. 10,1979 , at 4.

34. Under the ubiquitous "step-deal," a writer is paid in stages, as each new draft of his work is delivered. See Standard Form Freelance Television Writer's Employment Contract (on file with Yale Law Journal).

Because the Writers Guild forbids uncompensated work on speculation, writers shop their story ideas orally, in meetings with producers. The Guild tries to encourage storyand-teleplay deals by permitting "bargain rates," see Writers Guild of America, Basic Agreement, art. 13B, $\$ 7$ (c) (1977) (on file with Yale Law Journal); but, because producers own the basic rights to any story that they may commission, see id. art. 16B, they often commit themselves only to paying for the basic story, with options to go on to further stages of development. Even when writers and producers have sufficient contract leverage to retain their creative involvement in a property, persistent network interference can eventually drive them out, forcing them to abandon to network personnel the project's further development. See McGee, The Short Harried Life of Mrs. Columbo, AMERICAN Fild, June 1979, at 62.

35. E. BARNOUw, supra note 5, at 113-14.

36. Program makers are supposed to devise and produce shows that will attract mass audiences without unduly offending these audiences or too deeply moving them emotionally. Such ruffling, it is thought, will interfere with their ability to receive, recall, and respond to the commercial messages.

B. Shanks, The Cool Fire: How to Make It in Television 98 (1976). 
depiction of disagreeable realities that might hurt product sales. ${ }^{37}$ Such self-censorship is at least partially the result of the formal censorship exercised by each network's Department of Broadcast Standards and Practices, ${ }^{38}$ a procedure that reflects the economic significance of programming decisions; large advertisers may withdraw sponsorship of programs as a result of sensitive content. ${ }^{39}$

\section{Competitive Strategies}

The existence of three major viewing options in each time slot could, in theory, provide programs that meet different audience needs at all times. In practice, however, advertisers force the networks to compete for the largest group of consumers within each time period's audience instead of diversifying their programming to appeal to various audiences. ${ }^{40}$ This tendency to target just one segment is aggravated by "block" programming, a strategy designed to encourage viewers to stay tuned from one show to the next."1 Diversifying programs, such as public affairs broadcasts ${ }^{42}$ and locally produced programs, are therefore relegated to obscure time-slots when the normal audience is small or demographically unattractive to advertisers. ${ }^{43}$

Even during prime-time hours, ${ }^{44}$ prograrns with markedly divergent

37. See id. at 78 (comparing television to more outspoken and permissive media).

38. The scripts of every show must be submitted to network censors for final review before production may begin. Blum, Censorship in Television: $A$ Writer's Point of View, 8 Performing Arts Rev, 107, 112 (1976). Under this regime, the chill of "pre-censorship" affects the work of all programming professionals. See id. at 116.

39. See Schiefelbein, Guardians of the Airwaves, SATURdy REv., Sept. 16, 1978, at 26. Procter \& Gamble, the leading television advertiser, see The $567 \mathrm{Club}$ : 197S's network TV advertisers, Broddcistins, Mar. 12, 1979, at 78, insists that " [ $t]$ here will be no material on any of our programs which could in any way further the concept of business as cold, ruthless, and lacking all sentiment or spiritual motivation." $T$. GREEN, THE Universal Eye: The Wordd of Television 29 (1972) (quoting Procter \& Gamble memorandum). For examples of direct interference by sponsors in program content, see Media ANd the First Amendment, supra note 1, at 90.

40. For example, weekday afternoons are generally devoted to women's programs, even though there are millions of children in the audience. See Note, Diversity in Television Program Content: A Proposal for Sustaining Programming, 7 Colum. J.L. \& Soc. Pros. $319,329.30$ (1971).

41. See Media and the First Amendment, supra note 1, at $92-93$ (network concern for "audience flow").

42. Economic incentives prompt licensees to keep this body of programming as small as possible, despite public and regulatory pressure. E. BARNouw, supra note 5 , at 125 .

43. Note, supra note 40 , at 333 . More recent sampling of data reported on FCC Form 303A, which asks licensees to state minimum amounts of broadcast time devoted to public affairs, has confirmed that stations still prefer to schedule local and public affairs programs at obscure hours. See Chamberlin, The Impact of Public Affairs Programming Regulation: A Study of the FCC's Effectiveness, 23 J. Broadcasting 197, 204 (1979).

44. Prime-time hours are the daily peak-viewing hours, from 7:30 to 11:00 p.m.; viewing can reach a peak of between 90 and 100 million viewers at 9:00 o'clock each evening. 
appeal rarely compete directly. Because the particular mass audience preferred by advertisers can be measured by demographic ratings, most prime-time shows aim at young consumers of heavily advertised products. $^{45}$ Considerations of audience-flow and sponsor-preference discourage programmers from pitting unusual shows-as opposed to standard mass-audience fare-against their rivals' most successful programs. ${ }^{40}$

In a national system of more numerous choices, diversification might occur naturally through differentiation of familiar formats of popular entertainment ${ }^{47}$ as well as through introduction of new program formats designed and scheduled to meet the interests of special audiences large enough to reward the programmer with a satisfactory rating. ${ }^{48}$ As things stand, however, program diversification is riskier than imitation, ${ }^{49}$ and no one really knows whether the audience selects "popular" programs by enthusiasm or simply by comparative indifference. ${ }^{50}$

45. Advertisers hoping to reach young married households are aided by Nielsen's audience-measurement techniques, which produce demographic data that categorize audiences by age and sex. Popular shows that appeal predominantly to older audiences have been driven off the air by advertiser preferences. See E. BARNouw, supra note 5, at 71-73.

46. Unusual shows create "adjacency" problems, for programmers are convinced that "the audience for a given program may depend more on the type and nature of preceding and succeeding programs than on the program's 'intrinsic' popularity." TELEvision Economics, supra note 16 , at 96.

47. This would occur because smaller shares would obviate the necessity for "common denominator" and "Ieast offensive" programs designed to be watched by an indifferent coalition of viewer groups. Cf. Brown, Viewers' Dissatisfaction With TV Programs Found Increasing, N.Y. Times, Jan. 3, 1980, $\S \mathrm{C}$, at 18 , col. 1 (67\% of viewers reject idea that " 'people who run commercial television have my best interests at heart' "). The networks' reliance on common-denominator programs "is consistent with the (plausible) assumption that viewers would prefer to have programs somehow tailor made to their own tastes, but if this is impossible, will make do with some other program." Television Economics, supra note 16, at 54 n."e"; cf. F. MANKIEwicz \& J. SwERoLow, supra note 4, at 69-70 (viewer patterns substantiate "Least Objectionable Program" theory of viewer selection).

48. See note 25 supra. It is likely that networks that could expect only a $20 \%$ share of the audience would require demographic data that would target viewer groups of that size more accurately. Cf. note $\mathbf{5 0}$ infra (qualitative ratings might encourage advertisers to support preferred shows of smaller audiences).

49. See Television Economics, supra note 16, at 96 ("There is a role . . for the 'novel idea,' but most quality variation takes the form of providing more of those program 'values' or types that appear to be popular on the other networks.")

50. Some critics blame programming monotony on the fact that Nielsen ratings emphasize numbers alone and fail to include any index of viewer satisfaction. See Setlow, TV Ratings-There Just Might Be a Better Way, N.Y. Times, Dec. 31, 1978, $\S 2$, at 23, col. 4. Proponents of a qualitative measurement (" $Q$-factor") claim that its use might encourage advertisers to support diversifying programs addressed to socioeconomic and ethnic minorities because it would show the intensity of appreciation earned for the sponsor among the target audience. Id. But cf. Musel, The ratings everyone ignores, TV GuIDE, June 30, 1979, at 42 (English commercial broadcasters ignore available qualitative ratings; "advertisers are interested in the most-watched programs, not the most loved programs"). 


\section{The Failure of Current Regulation}

The 1934 Communications Act ${ }^{51}$ granted the FCC broad discretion to regulate in the "public convenience, interest, or necessity." "s2 But FCC pronouncements, while recognizing the goal of diversified program service, ${ }^{53}$ have been both controversial and ineffective. ${ }^{54}$ Although the focus of FCG concern over mass-audience television programming has been network dominance, ${ }^{55}$ it has never properly addressed the underlying economic causes of program regimentation.

\section{A. The Public Interest in Diversity}

The public interest standard ${ }^{56}$ has been invoked by the FCC in pronouncements about advertiser-supported programming since the first years of federal broadcast regulation. ${ }^{5 \tau}$ The operative rule ${ }^{58}$ ap-

51. Pub. L. No. 73-416, 48 Stat. 1064 (1934) (codified at 47 U.S.C. $\$ \S 151-609$ (1976)).

52. See 47 U.S.C. $\$ \$ 303,307,309,310$ (d) (1976) (granting FCC regulatory and licensing powers). The official phrase has been shortened to "the public interest standard" in common usage.

53. See H.R. Rep. No. 281, 88th Cong., 1st Sess. 28-30 (1963) (reprinting Feder.1L

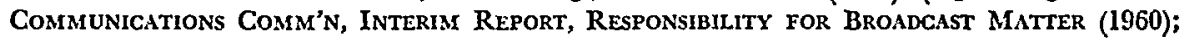
Federal Communications Comm'n, Television Network Program Procurement (1963)) (emphasizing that diversification is necessary to serve many interests of "cultural democracy") [hereinafter cited as FCC NETwORK REPORTS].

54. See Documents of Americin Broadcasting 125 (2d ed. F. Kahn 1973) (editorial note that FCC content-regulation "is among the most feared and least influential of the myriad forces" that shape programming).

55. See, e.g., FCC NETWORK REPORTs, supra note 53, at 45 (network program-procurement inquiry found that competition did not "decentralize the 'tremendous power' of networks over what the public may see and hear"); Commercial Television Network Practices, 62 F.C.C.2d 548, 549 (Notice of Inquiry), stayed, 67 F.C.C.2d 136 (1977), revived, 43 Fed. Reg. 50,126 (1978), expanded, 44 RAD. REg. 20 (P\&.F) 1674 (F.C.C. 1979) (FCC has undertaken inquiry to determine whether particular network practices-contractual, distributive, and economic-improperly compromise or restrict programming discretion of broadcast licensees).

56. The public interest standard first appeared in the Radio Act of 1927, Pub. L. No. 69-632, 44 Stat. 1162 (1927) (repealed 1934), but its use there was borrowed from public utility legislation. Coase, The Federal Communications Commission, 2 J.L. \& ECoN. 1, 8 (1959).

57. See Federal Radio Comm'n, Statement made by the commission on August 23, 1928, relative to public interest, convenience, or necessity, 2 F.R.C. ANN. REP. 166, 168 (1928) (public interest "best served by avoiding too much duplication of programs and types of programs" within listening area).

58. Despite the Communication Act's anti-censorship provision, 47 U.S.C. $\$ 326$ (1976), the public interest has been held to justify regulations forbidding some licensees to carry network programs. See National Broadcasting Co. v. United States, 319 U.S. 190 (1943). As a result, NBC was compelled to divest one of its two radio networks ("NBC-blue"), which became ABC. E. Barnouw, Tube of Plenty 95-96 (1975). Though the inevitable effect of these FCC regulations on the free speech of some NBC affiliates was minimized by Justice Frankfurter in the NBC opinion, 319 U.S. at 226-27, it could have constituted an invalid prior restraint under traditional First Amendment principles, $c f$. Near v. Minnesota, 283 U.S. 697, 713-14 (1931) (First Amendment protects against "previous restraints" on freedom of press). 
pears to be that broadcasters are protected by the First Amendment except for specific instances in which the FCC has officially adopted a rule or policy. ${ }^{59}$ Although the FCC purports to minimize any regulation of content, ${ }^{00}$ broadcasters, as governmental licensees, are uniquely situated in our constitutional system. ${ }^{61}$ Before the FCC decides to intrude, it must balance the public interest in diversity against the broadcasters' First Amendment rights. ${ }^{62}$ Comparisons with modern First Amendment principles establish the validity of FCC action to promote program diversification whenever unacceptable regimentation by private forces undermines a "free trade in ideas." 33 Overarching constitutional analysis favors a "multitude of tongues," ${ }^{4}$ and this principle has

59. See Columbia Broadcasting Sys. v. Democratic Nat'l Comm., 412 U.S. 94, 120-21, 122 (1973) (private licensees enjoy editorial privilege in unregulated areas while FCC has "flexibility" to adopt regulation in public interest); Writers Guild of America, West, Inc. v. FCC, 423 F. Supp. 1064, 1155-57 (C.D. Cal. 1976), rev'd on other grounds sub nom. Writers Guild of America, West, Inc. v. American Broadcasting Co., 609 F.2d 355 (9th Cir. 1979) (finding that FCC violated First Amendment by issuing threats of government action and failing to observe requisite procedural safeguards in adopting official policy).

60. See, e.g., Amendment of $\S 73.658(\mathrm{k}), 60$ F.C.C.2d 641, 643 (1976) (citing general principle of governmental non-involvement in content as especially applicable in area of entertainment programming).

61. In Red Lion Broadcasting Co. v. FCC, 395 U.S. 367 (1969), the Supreme Court upheld the FCC's fairness doctrine, 47 C.F.R. $\$ \$ 73,123, .300, .598, .679$ (1978), against a licensee's First Amendment challenge. In the course of its unanimous opinion, the Court said that a licensee did not have any right to monopolize the ideas disseminated over its channel, 395 U.S. at 389 , and upheld a type of regulation that was subsequently held unconstitutional in a state law affecting printed media, see Miami Herald Publishing Co. v. Tornillo, 418 U.S. 241 (1974). Although Red Lion has been substantially eroded by subsequent decisions, it continues to stand for the proposition that the societal interest in diversification of broadcast material is strong enough to override traditional First Amendment prohibitions and to support FCC regulation in the public interest.

62. See National Ass'n of Theatre Owners v. FCC, 420 F.2d 194, 207 (D.C. Cir. 1969), cert. denied, 397 U.S. 922 (1970) ("In seeking to provide the broadcasting media with the diversity demanded by the first amendment, ... the Commission must avoid the perils of ... abdication which would allow those possessing the most economic power to dictate what may be heard, and of censorship.")

63. Abrams v. United States, 250 U.S. 616, 630 (1919) (Holmes, J., dissenting). Mr. Justice Holmes relied upon the "competition of the market" to test the truth of conflicting ideas and was confident that the truth would triumph in the marketplace. Id. Fifty years later, the Red Lion Court held that a licensee was "a proxy or fiduciary with obligations to present those views and voices which ... would otherwise, by necessity, be barred from the airwaves," 395 U.S. at 389, and approved an economic rationale for FCC regulations lest "station owners and a few networks ... have unfettered power to make time available only to the highest bidders," id. at 392. But cf. Columbia Broadcasting Sys. v. Democratic Nat'l Comm., 412 U.S. 94 (1973) (no constitutional right of access for editorial advertisers).

64. United States v. Associated Press, 52 F. Supp. 362, 372 (S.D.N.Y. 1943) (L. Hand, J.), aff'd, 326 U.S. 1 (1945). In affirming a judgment against the defendant in this government antitrust suit, the Court stated that the First "Amendment rests on the assumption that the widest possible dissemination of information from diverse and antagonistic sources is essential to the welfare of the public...." Id. at 20. 
eventuated in judicial recognition of society's interest in the free flow of information and opinion through the mass media. ${ }^{05}$

Indeed, the public interest in diversity is constitutionally and legislatively protected in several noteworthy areas outside of broadcast regulation. The First Amendment has been held to protect the media from private legal action; the societal interest in "wide-open" debate on public issues constrains the newsworthy subject's right to claim damages for libel ${ }^{66}$ and circumscribes his or her right of privacy. ${ }^{67}$ Legislation granting reporters the right to protect confidential sources ${ }^{\mathrm{BS}}$ recognizes and protects a privilege claimed on behalf of the public interest in receiving news. ${ }^{69}$ The equitable doctrine of "fair use" in copyright law has been justified by "the public interest in the free dissemination of information," 70 and Congress incorporated that doctrine into the new Copyright Act. ${ }^{71}$ The public interest in diversified news, comment, and opinion has even been subsumed into Professor Emerson's First Amendment theory as an independent constitutional right to know. ${ }^{72}$ Thus, the public interest in diversity is broad enough to include FCC regulation designed to promote diversification of television entertainment programs. ${ }^{73}$

65. See First Nat'l Bank of Boston v. Bellotti, 435 U.S. 765, 783 (1978) (citing importance of First Amendment's role in dissemination of information and ideas); Virginia State Bd. of Pharmacy v. Virginia Citizens Consumer Council, Inc., 425 U.S. 748, 756.57 (1976) ("protection afforded is to the communication, to its source and to its recipients both").

66. New York Times Co. v. Sullivan, 376 U.S. 254, $269-70$ (1964). But see Hutchinson v. Proxmire, 99 S. Ct. 2675, 2688 (1979) (allowing action for libel by plaintiff who "can [not] be said to have invited that degree of public attention ... essential" to justify First Amendment defense).

67. Time, Inc. v. Hill, 385 U.S. 374, 388 (1967).

68. E.g., N.J. Stat. ANN. \$ 2A:84A-21 (West 1976 \& Supp. 1979).

69. The privilege, however, remains purely statutory. See Branzburg v. Hayes, 408 U.S. 665 (1972) (denying existence of constitutional reporter's privilege).

70. Rosemont Enterprises, Inc. v. Random House, Inc., 366 F.2d 303, 307 (2d Cir. 1966), cert. denied, 385 U.S. 1009 (1967).

71. General Revision of Copyright Law, Pub. L. No. 94-553, 90 Stat. 2541 (1976) (codified at 17 U.S.C. $\$ \$ 101-810$ ).

72. See Emerson, Legal Foundations of the Right to Know, 1976 WASH. U.L.Q. 1, 2. Professor Emerson argues that the audience's right is an integral part of the system of free expression under the First Amendment, for the right to know is reciprocal to the right to communicate.

73. The Supreme Court has rejected any "suggestion that the constitutional protection for a free press applies only to the exposition of ideas. The line between the informing and the entertaining is too elusive for the protection of that basic right." Wvinters v. New York, 333 U.S. 507, 510 (1948). Television programming plays an important role in conveying opinions, shaping attitudes, and expressing ideas, U.S. Comm'N oN Civil Rights, supra note 6, at 44, and the fact that the number of sets in American homes is nearly twice the total daily circulation of newspapers, Cater, Introduction: Television and Thinking People, in Television as a Social Force 1, 1 (D. Cater \& R. Adler eds. 1975), suggests strongly that there is a reasonable basis in modern constitutional law upon which the Supreme Court could uphold FCC regulation to diversify entertainment programs in the public interest. 
Appropriate regulatory policy, however, should minimize inquiries into content. ${ }^{74}$ To achieve this, the public interest in diversification would best be served by channeling editorial discretion in such a way that it would address the needs of a sophisticated and varied society; ${ }^{75}$ past attempts to achieve this result have been frustrated by First Amendment considerations precluding strict enforcement. ${ }^{76}$ In addition, critics charge that "capture" of the FCC by industry forces has prevented impartial regulatory assessment of the public interest. ${ }^{.7}$

\section{B. The Impact of Current Regulation}

The congressional rationale behind federal regulation of broadcasters was based primarily upon efficient management of the broadcast spectrum, but the legislative debate shows a dawning awareness of the implications for definition of program content. ${ }^{88}$ The classic principle of early federal regulation urged that the public interest standard required a licensee to serve all the interests of its community because broadcasting was uniquely the audience's medium. ${ }^{70}$ Currently the FCG requires licensees to ascertain the problems of their communities, ${ }^{80}$ to hold themselves out annually for public comments, ${ }^{81}$ and to program according to broad categories spanning an official range of presumed viewer interests. ${ }^{82}$

74. FCC v. National Citizens Comm. for Broadcasting, 436 U.S. 775, 801-02 (1978).

75. It is not appropriate for the FCC to dictate which needs the networks should address. Cf. Hannegan v. Esquire, Inc., 327 U.S. 146 (1946) (Postmaster may not withdraw mailing privileges from magazine because it offends personal sensibilities). Audience study techniques can identify unmet needs and interests. See p. 718 infra.

76. Robinson, supra note 9 , at 261 .

77. Id. at $189-93$.

78. See 67 Cong. Rec. 5479 (1926) (remarks of Rep. White) ("If enacted into law, the broadcasting privilege will not be a right of selfishness. It will rest upon an assurance of public interest to be served.") Although the legislative debates indicate an intent to preclude the possibility of unconstitutional interference with free speech, see, e.g., id. at 5480 (remarks of Rep. White), shortly after enactment of the regulatory scheme, the Court of Appeals, reviewing the FRC's denial of renewal to a medical quack, held that the Commission's "undoubted right to take note of appellant's past conduct ... is not censorship," KFKB Broadcasting Ass'n v. Federal Radio Comm'n, 47 F.2d 670, 672 (D.C. Cir. 1931).

79. See, e.g., FCC v. Sanders Bros. Radio Station, 309 U.S. 470, 475 (1940) (important element of public interest is ability of licensee to render best service to local community); Great Lakes Broadcasting Co., 3 F.R.C. ANN. REP. 32, 34 (1929), modified on other grounds, 37 F.2d 993 (D.C. Cir.), cert. dismissed, 281 U.S. 706 (1930) ("entire listening public . . . is entitled to service"; if programs valuable only to small portion of public, "rest of the listeners are being discriminated against").

80. See Ascertainment of Community Problems, 57 F.C.C.2d 418, modified, 61 F.C.C.2d 1 (1976) (defining procedures sufficient to satisfy requirement).

81. See 47 C.F.R. $\$ 73.1202$ (1978) (requiring public notice of licensee obligations).

82. See En banc Programing Inquiry, 44 F.C.C. 2303, 2314 (1960) (listing fourteen program elements); FCC Form 301, reprinted in RAD. REG. (P\&F) 98:301-328 (Forms 
Because of the industry's mass-audience economics, broadcasters resist the FCG's program policies. They purport to comply with those policies, however, in order to avoid license renewal challenges. ${ }^{83}$ Yet the FCC's failure to formulate criteria for substantial program service that would promote imaginative and responsive programming ${ }^{84}$ has meant that, despite the high administrative costs of contested renewal proceedings, ${ }^{85}$ the incumbent's license will be renewed unless some deliberate programming abuse can be shown. ${ }^{86}$ As a result, FCG involvement is both paternalistic and ineffective.

The FCG normally grants broadcasters broad discretion in selecting entertainment programs; it distinguishes that field from "merit" programming ${ }^{87}$ and permits a licensee to make editorial decisions about entertainment programs solely on the basis of economic self-interest. ${ }^{88}$

1978) (license application "suggesting" use of same fourteen program elements). Licensees are required to keep a station program log that classifies each program by type and origin. See 47 C.F.R. $\$ 73.670$ (1978); cf. FCC Form 303A (1978) (commercial licensees' annual programming report) (on file with Yale Law Journal).

83. A licensee is vulnerable to renewal proceedings every three years. 47 U.S.C. $\$ 307$ (d) (1976). Viewers may contest the license renewal. Id. $\$ 309$ (d); see Office of Communication of the United Church of Christ v. FCC, 359 F.2d 994 (D.C. Cir. 1966). The FCC, however, remains protective of its licensees' editorial discretion absent a showing of bad faith or deliberate abuse. See, e.g., KCOP Television, Inc., 45 RAD. REg. 2D (P\&F) 1063, 1066 (F.C.C. 1979); Note, Use of Petitions by Minority Groups to Deny Broadcast License Renewals, 1978 DukE L.J. 271, 274-77.

Compliance with program policies is a form of insurance against challenges from the public at the time of renewal. See Television Economics, supra note 16, at 5 . The renewal of an uncontested license does not raise program issues, for it is little more than a formality. See Johnson \& Dystel, $A$ Day in the Life: The Federal Communications Commission, 82 YALE L.J. 1575, $1604-05$ (1973). However, informal quotas on public affairs and local programs may have arisen, at least in the view of broadcasters. See Schofield, supra note 16, at 40 (station manager indicates that showing of less than $5 \%$ local programs may trigger FCC to "take a closer look").

84. In requiring periodic renewal, Congress provided for competition to existing licensees by affording new parties an opportunity to apply for the same frequency. Geller, The Comparative Renewal Process in Television: Problems and Suggested Solutions, 61 VA. L. REv. 471, 472-75 (1975). When a competing application is filed, the absence of any formal standard of "substantial program service" can become critical. See, e.g., Central Fla. Enterprises v. FCC, 598 F.2d 37, $49-50$ (D.C. Cir. 1978), cert. dismissed sub nom. Cowles Broadcasting, Inc. v. Central Fla. Enterprises, 99 S. Ct. 2189 (1979) (no basis in record for FCC finding of substantial program service by incumbent licensee). Nevertheless, the FCC perseveres in its refusal to adopt officially any "quantitative program standards." See Broadcast Renewal Applicant, 66 F.C.C.2d 419, 429 (1977), aff'd sub nom. National Black Media Coalition v. FCC, 589 F.2d 578 (D.C. Cir. 1978).

85. See Robinson, supra note 9, at $242 \mathrm{n} .171$ (challenger and incumbent incurred combined costs of $\$ 3.5$ million in initial hearing stage of comparative renewal).

86. But see Central Fla. Enterprises v. FCC, 598 F.2d 37, 50 (D.C. Cir. 1978), cert. dismissed sub. nom. Cowles Broadcasting, Inc. v. Central Fla. Enterprises, 99 S. Ct. 2189 (1979) (remanding with remark that FCG finding of incumbent's "substantial" service makes decision "completely opaque to judicial review" and "fall[s] somewhere on the distant side of arbitrary").

87. Amendment of $\$ 73.658(\mathrm{k}), 60$ F.C.C.2d 641,643 (1976).

88. See id. at 644 (editorial decisions may be governed by marketplace forces). But see WNCN Listeners Guild v. FCC, 5 MediA L. ReP. (BNA) 1449 (D.C. Cir. 1979) (en banc), 
Thus, entertainment programs produced by cost-effective national networks dominate the "local" broadcasting system. ${ }^{89}$ The FCC's one attempt to curtail network power and regulate choice-of-entertainment decisions-by adoption of a Prime Time Access Rule (PTAR) ${ }^{90}-$ failed. PTAR addressed the restrictive economics of national massaudience programming by limiting affiliates' discretion to accept network programs. ${ }^{91}$ The underlying theory was that, if network dominance could be curtailed during the most popular viewing hours, broadcasters would be free to select diversifying programs of special or local interest to round out the evening schedule. ${ }^{92}$ Yet economic factors continued to favor mass-audience programs produced for national distribution. ${ }^{93}$ Economists correctly predicted that the quality of shows would decline because national syndicators have the same program objectives as networks, yet do not enjoy comparable economies of distribution. ${ }^{94}$ The lesson of PTAR is that "network dominance" can be ascribed to national mass-audience programming competition. ${ }^{95}$ The experiment has shown that local broadcasters, as a result of the same economic and

rev'g 60 F.C.C.2d 858 (1976), cert. granted, 48 U.S.L.W. 3565 (U.S. March 3, 1980) (Nos. 79-824 to 827) (rejecting FCC policy of non-interference in transfers of radio license involving loss of unique entertainment format and criticizing blanket reliance on market forces to serve pluralistic audiences).

89. See Television Economics, supra note 16, at 97 (incentive to carry network programs based on comparison of network compensation with "profits . . [stations] could earn by using other program sources").

90. 47 C.F.R. $\$ 73.658(\mathrm{k})$ (1978). The rule provides that affiliates in the top fifty markets may air no more than three hours of network programs, with certain exceptions, between 7 and 11 p.m. Id. The Commission adopted the rule in 1970, after a lengthy study of network practices. See Schuessler, FCC Regulation of the Network Television Program Procurement Process: An Attempt to Regulate the Laws of Economics? 73 Nw. U.L. REv. 227, 235-36 (1978).

91. The Rule has been upheld twice against claims that it restricts speech unconstitutionally. See, e.g., National Ass'n of Independent Television Producers and Distribs. v. FCC, 516 F.2d 526 (2d Cir. 1975); Mount Mansfield Television v. FCC, 442 F.2d 470 (2d Cir. 1971).

92. See Consideration of the Operation of, and Possible Changes in, the "Prime Time Access Rule," 44 F.C.C.2d 1081, 1136-37 (1974) (emphasizing expectation that broadcasters will dedicate appropriate portion of cleared time to community needs).

93. Neither the court of appeals nor the FCC has found the admittedly low quality of access programs a sufficient reason to reverse or amend the rule. See National Ass'n of Independent Television Producers and Distribs. v. FCC, 516 F.2d 526, 536 (2d Cir. 1975) (mass tastes favoring game shows over documentaries are not concern of FCC); Amendment of $\$ 73.658(k), 60$ F.C.C.2d 641, 645 (1976) (rejecting proposed amendment to bar more than one weekly episode of same program in access time).

94. See, e.g., R. NoLl, supra note 11, at 83-89; Crandall, supra note 9, at 406-07. Because the least costly popular shows are favored, the production economies gained in producing and distributing several episodes of the same show each week ("stripping") have given quiz and variety shows a significant price advantage. The FCC has refused to amend PTAR to bar stripping in access time. See Amendment of $\$ 73.658(\mathrm{k}), 60$ F.C.C.2d 611 (1976).

95. A recent FCC study of the networks' relations with their affiliates confirms this conclusion. See Holsendolph, supra note 12. 
competitive forces that govern networks, prefer to program shows with the broadest appeal. ${ }^{96}$ The scarcity of stations in most local markets ${ }^{97}$ means that special audiences are still too small to evoke diversified programs from profit-maximizing syndicators, who seek the widest national distribution through markets in which the mass-audience program competition still prevails. ${ }^{98}$

\section{Promoting Diversification}

Critics of current broadcast regulation have proposed various alternative approaches that might effectuate the public interest in diversity. The three major proposals include an antitrust attack on network economic concentration, public access regulation, and deregulation of licensees. Yet none of these proposals addresses those economic features of broadcasting that cause program regimentation. Thus a new approach, which focuses the existing regulatory standard on the industry structure and business practices that stifle diversity, is necessary.

\section{A. The Antitrust Attack}

Because the networks wield enormous power and dominate the medium with their programs, television undoubtedly presents an appealing target for trust-busters. ${ }^{99}$ Antitrust suits might be employed by the government to curtail network power, ${ }^{100}$ but only the most super-

96. See Schuessler, stupra note 90, at 292-96 (data available to FCC at time of PTAR adoption indicated that rule's ameliorative purpose would be frustrated by economic forces).

97. Cf. p. 696 supra (only $60 \%$ of viewers receive more than three stations).

98. A syndicator of special-interest programs could hope, at best, to sell its product in the rare markets that enjoy five or six local stations, in which equal shares distributed more or less evenly among the competitors would be no larger than the particular specialinterest audience. See p. 697 supra. Because those markets are so few in number, the aggregate number of special-interest viewers available to any syndicator remains low; even if the cost-per-viewer does permit positive revenues, that cost will remain too high to maximize syndication profits.

99. The Department of Justice has most recently filed an antitrust suit against the National Association of Broadcasters (NAB), alleging that "time standards" included in its Television Code-voluntary limitations on the duration and frequency of commercials to be observed by subscribing broadcasters-violate the Sherman Act, 15 U.S.C. $\$ 1$ (1976). See Complaint, United States v. National Ass'n of Broadcasters, No. 79-1549 (filed D.D.C. June 14, 1979) (seeking injunctive relief against NAB and subscribing broadcasters). Although this latest action must be termed part of an "antitrust attack" against television, its relevance to the programming issues discussed in this Note is tangential.

100. The Department of Justice brought an antitrust suit against the networks, seeking to reduce their control over producers and program-suppliers. See Fastow, Competition, Competitors and the Government's Suit Against the Television Networks, 22 ANTITRUST BULL. 517, 522 (1977). Although the suits against CBS and ABC are pending, see 
ficial logic would compel a conclusion that such measures could effect appreciable diversification of programming. Economic concentration at the network level, conspicuous as it may be, is a strawman for anyone arguing that a network oligopoly accounts for the monotony of mass-audience programming; each local market represents an oligopoly as well. Moreover, the program production industry remains large and diverse. ${ }^{101}$ Thus, no moderate antitrust remedy designed to modify network behavior would reach the underlying restraint of limited channels, which would continue to make competing broadcasters prefer mass-audience programs.

As for structural antitrust remedies, the government might seek a decree limiting the amount of network programming that any affiliate could include in its daily schedule. Depending upon the specific rules adopted, two possible outcomes are foreseeable:102 the three networks might remain in place as dominant suppliers, with available timeslots becoming "access time" for syndicators; ${ }^{103}$ or, assuming that too much syndication time became an inefficient accommodation to the needs of national advertisers, ${ }^{104}$ additional competitors could arise to distribute "networked" programs for each available time-slot in every station's schedule. ${ }^{105}$ In this latter case, the three networks might

Where Things Stand, Brosdcasting, Jan. 7, 1980, at 22, NBC entered into a consent decree, United States v. National Broadcasting Co., 449 F. Supp. 1127 (C.D. Cal. 1978). The judgment bars NBC from exploiting "enormous market power" in its contracts with program suppliers by including provisions that had been alleged to have anticompetitive effects. See id. at 1145 . The court expressed reservations as to the appropriateness of the antitrust approach, however, and explained that suitable FCC regulation would have been preferable. Id. One commentator has argued that the changes sought by the government do not promote efficiency, but merely prevent practices that violate no "antitrust theme." Fastow, supra, at 530-31.

101. R. Noll, supra note 11, at 44; B. OWEN, supra note 18, at 102; Television Economics, supra note 16 , at $26,28$.

102. If permitted to do so, the networks would take the most profitable hours of the broadcast day, starting with prime time, and the first outcome discussed in the text would be the likely result, (assuming that network time was still adequate to meet na. tional advertisers' needs). A more complete remedy, however, would require networks to compete for every available slot in each station's schedule instead of preemptively taking the most valuable time for themselves. In this latter case, additional distributors of "networked" programs-the second foreseeable outcome discussed in the text-would be bound to arise.

103. Because syndication does not offer the same distributional and risk-spreading efficiencies as networking, the quality of programs would decline as economic resources were absorbed by higher costs of distribution and enhanced risk. Cf. p. 707 supra (economists predicted decline in quality of programs scheduled in access time under PTAR).

104. Advertiser demand for network time appears to be very strong. See, e.g., Dempsey, Big Ad Buyers Race for Web Time, VARIETY, June 6, 1979, at 1, col. 3.

105. Satellite technology presently exists to facilitate occasional networking, with its attendant distributional economies. See Brown, Satellite Offer May Aid TV Stations' 
eventually end up competing with any number of newcomers for each place on a station's schedule, but heavy costs would certainly be incurred to organize a market with so many complex transactions. ${ }^{100}$

However, even the boldest reorganization of the existing marketplace would not affect the competitive dysfunction of limited outlets in local markets, or advance the public interest in diversity. Under either structural outcome, both the stations and their suppliers would still compete with programs designed to capture at least thirty percent of the viewers in each local market, and thus networked or syndicated programs would still be designed to capture thirty percent of the national audience. ${ }^{107}$

\section{B. Public Access Regulation}

A second alternative would extend public access to broadcast facilities to present a fuller range of viewpoints. ${ }^{108}$ Although access regulation might be effective in overcoming one-sided presentation of issues and commentary, ${ }^{109}$ it would not foster diversification of entertainment programming.

Abolishing network control of programs to create a common-carrier-

Programming, N.Y. Times, Mar. 20, 1979, § C, at 11, col. 1. As envisioned here, no station would have a permanent network affiliation, and no "network" would enjoy a permanent or guaranteed collection of local stations through which to reach a national audience.

106. Distributors would want to bargain for the most farorable terms in each local market, while competing broadcasters, in line to bid against each other for a program, would have to get some idea of its likely appeal in order to bargain effectively. Scheduling problems would compound the complexity of each transaction. The costs of dealing with all these problems would be subtracted from money available to produce programs.

107. Cf. Owen, supra note 12, at 236 (finding that similar plan would "probably" not change number or quality of viewing options). Numerous networks in this instance are to be distinguished from the six-network model discussed above, see pp. 697-98 supra, which hypothesized six national networks in simultaneous competition for audiences, not six networks competing for three channels as a means of access to audiences.

108. Advocates of public access claim that novel and unpopular ideas, projected from a soapbox, can never compete with the safe, establishrnent orthodoxies purveyed by giant media conglomerates. See, e.g., Barron, Access to the Press-A New First Amendment Right, 80 HARV. L. REv. 1641, 1653 (1967) (community's opportunity for free expression rests on abundance of opportunities to secure expression in media with largest impact). The Supreme Court has avoided recognizing any right of access, see, e.g., FCC v. Midwest Video Corp., 99 S. Ct. 1435 (1979) (invalidating FCC requirement of "access channels" in cable TV); Columbia Broadcasting Sys. v. Democratic Nat'l Comm., 412 U.S. 94 (1973) (denying constitutional claim of access to television for paid editorial advertising), but has approved case-by-case regulatory prescription of limited access to broadcast media to reply to personal attacks, see Red Lion Broadcasting Co. v. FCC, 395 U.S. 367 (1969).

109. The FCC is now considering a requirement that licensees furnish one hour of access-time per week for commentary and opinion in news and public affairs. Half the time would be allocated on a first-come, first-served basis, and half on a "representative spokesperson" basis. See National Citizens Comm. for Broadcasting v. FCC, 567 F.2d 1095, 1112-14 (D.C. Cir. 1977), cert. denied, 436 U.S. 926 (1978). 
like obligation to make program distribution facilities available to the highest bidder for each block of time would be precluded by the terms of the Communications Act. ${ }^{110}$ However, regulation might be adopted that would permit audiences and advertisers to rely on network program supply, but that would create an administrative remedy to override network program policies on behalf of particularly meritorious programs. ${ }^{111}$ But case-by-case review of program material rejected by the networks would be an administrative headache. ${ }^{112}$ Furthermore, such a right-of-access solution threatens private editorial discretion, turning bureaucrats and appellate judges into television's executive programmers. ${ }^{113}$ Aside from the economic problem of subsidizing diversified programs, ${ }^{114}$ the dangers and burdens of intruding so far upon television's editorial decisionmaking caution against a system of diversification by administrative decree.

\section{Deregulating Licensees}

The system of broadcast regulation rests on the premise that the broadcast spectrum is public property; accordingly, the licensee is not

110. See 47 U.S.C. $\$ 153(\mathrm{~h})$ (1976) (“a person engaged in radio broadcasting shall not . . . be deemed a common carrier.") Amending the law to permit such a system would be unlikely to promote diversity because competitive bidding would undoubtedly foreclose access to all parties but advertisers. Whether developed by sponsors, advertising agencies, or independent producers, programs might thus become even more blatantly commercial.

111. A writer or producer could petition for administrative review of a network's rejection of program material. The FCC would be the logical forum for such review. The Commission might establish a panel of sociological, psychological, educational, and entertainment experts to evaluate the diversifying impact of a rejected program.

112. The threshold task of defining what constitutes rejection "for cause" would be arduous; given that no constitutional right of access has been recognized, see note 108 supra, the regulatory exception would have to be drawn narrowly to withstand a broadcaster's First Amendment challenge. Nevertheless, regulators would be inundated by a flood of complaints from disappointed creators seeking to establish the distinctiveness of particular programs, and by broadcasters' rebuttals. The ramifications of such a review procedure could exceed the difficulties encountered in administration of the fairness doctrine, which purports to be bilateral. See, e.g., American Security Council Educ. Foundation v. FCC, 607 F.2d 438, 448 (D.C. Cir. 1979) (en banc), cert. denied, 48 U.S.L.W. 3427 (U.S. Jan. 8, 1980) (No. 79-515) (dismissing fairness complaint) (massive empirical study of network news reports regarding national security failed to define "controversial issue" well enough to demonstrate imbalance).

113. Cf. Columbia Broadcasting Sys. v. Democratic Nat'l Comm., 412 U.S. 94, 126-27 (1973) (recognizing that active administrative role neither feasible nor constitutional).

114. Costs of production would have to be defrayed. An administrative system of access-by-right, however, would probably look only for unreasonably inflated expenses in deciding on a proposal, lest the networks be afforded an opportunity to litigate the reasonableness of every expense in each production. After a proposal had been adopted by decree, the network would presumably have the burden of defraying production costs for a show that might have no appeal to advertisers. Cf. pp. 699-700 supra (discussing advertiser preferences). 
permitted to own its frequency. ${ }^{115}$ However, the validity of this idea was challenged by Professor Coase twenty years ago.116 In evident sympathy with both Coase and a more recent proposal to establish property rights in the spectrum, ${ }^{117}$ a 1979 legislative proposal ${ }^{118}$ sought to repeal the 1934 Communications Act, ${ }^{119}$ replace the FCC with a new regulatory agency, ${ }^{120}$ and eliminate the jeopardy of periodic license renewals. ${ }^{121}$ The 1979 proposal-the most recent draft of what is known as the Van Deerlin Bill ${ }^{122}$-did not purport to convey inalienable property rights, ${ }^{123}$ but did declare that economic forcesnot government regulation-are the best device for public control of the airwaves. ${ }^{124}$

Although the Van Deerlin Bill recognizes the existence of market forces in broadcasting, it includes no innovations to counter the massaudience economics that regiment programming. ${ }^{125}$ Its most con-

115. See, e.g., Red Lion Broadcasting Co. v. FCC, 395 U.S. 367, 394 (1969) (“[1]icenses ... do not confer ownership"); WNCN Listeners Guild v. FCC, 5 MEdi L. REP. (BNA) 1449 (D.C. Cir. 1979) (en banc), cert. granted, 48 U.S.L.W. 3565 (U.S. March 3, 1980) (Nos. 79-824 to 827) (citing "common and undivided ownership of the airwaves by all of the people").

116. See Coase, supra note 56, at 17.40 (arguing that emergence of new technology did not justify such radical change in existing legal and economic system). Other economists have attacked public regulation as costly and inefficient, see, e.g., B. Owen, supra note 18, at 108-11 (discussing Posner's "taxation by regulation" theory), and challenged the public interest standard of spectrum allocation, see, e.g., Webbink, How Not to Measure the Value of a Scarce Resource: The Land-Mobile Controversy, 23 FED. CoM. B.J. 202 (1969) (FCC rulemaking procedures economically inefficient).

117. See DeVany, Eckert, Meyers, O'Hara, \& Scott, A Property System for Market Allocation of the Electromagnetic Spectrum: A Legal-Economic-Engineering Study, 21 STAN. L. REv. 1499 (1969).

118. H.R. 3333, 96th Cong., 1st Sess. (1979).

119. Id. § 804 .

120. The bill creates a Communications Regulatory Commission (CRC), id. $\$ \S 211$. 248 , which would issue licenses and regulate broadcasters "to ensure the most efficient and diverse use of the electromagnetic frequency spectrum," id. $\$ 413$ (a). Although the bill's structure appears to be derived from the 1934 Act, it reserves the broader public interest standard only for contingencies in which "it has been determined that marketplace forces are deficient." $I d$. $\$ 411(1)$.

121. Indefinite licenses would be granted to television stations after two probationary five-year license periods. $I d$. $\$ 461$. The bill not only eliminates the periodic jeopardy of license renewals, but also proposes barring consideration of competing applications at renewal of the probationary licenses. $I d . \$ 464(\mathrm{a})$.

122. This draft was significantly revised from the first version introduced by Representative Van Deerlin. See H.R. 13015, 95th Cong., 2d Sess. (1978).

123. The indefinite licenses are neither unconditional, H.R. 3333, 96th Cong., 1st Sess. $\S \S 462-466(1979)$, nor irrevocable, id. $\$ 418$.

124. Id. $\$ 411(1)$.

125. The bill does, however, retain measures affecting television programs. See id. $\$ 462$ (requiring public-affairs and local programs in daily schedule; retaining fairness doctrine); $i d . \S 463$ (equal opportunity for political candidates). 
troversial feature, the annual spectrum resource fee, ${ }^{126}$ would have required broadcasters to pay back some of their profits for the privilege of their licenses, but the legislation would have abolished any vestige of public interest control over the mass-audience economics of entertainment programming. ${ }^{127}$ The Van Deerlin Bill was withdrawn after receiving unfavorable comments from broadcasters and audience-representatives alike. ${ }^{128}$ In the future, deregulation in return for payment of an annual license fee will remain inadvisable unless it is tied to a plan to recirculate all licensing revenues for use in making diversified programs available to television viewers. ${ }^{129}$

\section{Regulating Diversity}

None of the three alternative proposals seems likely to ease the complex economic forces that strangle diversity. What is needed is not a new law; the structure of the 1934 Act is still sound. Rather than attempting to police content and pressure licensees to offer diversified programming, the FCC should attack the industry practices that militate against editorial enterprise, artistic freedom, and diversified schedules.

Rejecting the policy of localism to foster increased national competition seems neither fair nor feasible at this late stage. ${ }^{130}$ The FCC

126. See id. $\$ 411$ (Congress finds that spectrum resource fee would be incentive to more efficient allocation and use of spectrum); $i d$. $\$ 414$ (CRC shall assess annual spectrum resource fee for all users).

127. Whether this would have had any noticeable effect on the programs themselves is doubtful. Cf. p. 706 supra (FCC permits licensees to choose entertainment programs on basis of economic self-interest). It does seem likely, however, that the margin for riskier or less popular programs would have been reduced once the spectrum fee was added to the cost of doing business. Insofar as that was true, the bill would effectively have impeded diversification.

128. See Rewrite written off, Broadcasting, July 16, 1979, at 24 (reporting "intense pressure" against bill by citizens' groups and broadcasters).

129. See H.R. 3333, 96th Cong., lst Sess. $\$ 414(\mathrm{~d})$ (1979) (fees to be paid into general trcasury funds by CRC). The bill did authorize annual appropriations for public telecommunications. See $i d$. $\$ 614$ (\$1.50 per capita of national population). According to the Carnegie Commission on the Future of Public Broadcasting, however, the authorized appropriation would have been inadequate to help fund an independent public telecommunications system strong enough to compete with commercial service. CARNEGIE Comm'n, A Public Trust: Report on the future of Public Broadcasting 118-19 (1979) (recommending annual federal funding of $\$ 590$ million).

130. Rejection of localism would be unfair because expectations of protected monopoly profits have been capitalized in the price of sale whenever broadcasting stations and their licenses have changed hands. See Levin, Economic Effects of Broadcast Licensing, $72 \mathrm{~J}$. Political Econ. 151, 161-62 (1964) (sizable premiums paid for licenses "really constitute the price of entering a regulated market.") Thus the original beneficiaries of the policy of localism may already have reaped their gains, leaving secondary and tertiary buyerswho are receiving no more than a normal return on their investment-to bear the financial 
itself appears to be relying on promising new technology to ameliorate scarcity and facilitate distribution of diversified programs. ${ }^{131}$ Certainly, technological changes are imminent. Over time, these changes might obviate the current economic problems and facilitate the production and distribution of diversified programs. Cable television, already widely available, dramatically increases the number of broadcast signals that any home can receive ${ }^{132}$ and helps create "superstations" by importing the signals of distant independent stations. ${ }^{133}$ For the time being, however, new program services distributed over cable are specializing in familiar formats, such as news or sports, rather than undertaking the broad diversification that optimists might expect. ${ }^{134}$ "Pay-as-you-go" home entertainment media, such as video disks, cassettes, and pay-TV, are more promising because they avoid the economic inefficiencies of public goods and help assure that intensely felt needs will be met by production and pricing for direct sale to consumers. ${ }^{135}$ It is still too early, however, to make any confident predictions about whether "free" television will be superannuated or

hardship of such a radical reversal. Rejection of localism would also be infeasible because of the high regulatory costs for planning and start-up that would be involved in any national reallocation of frequency space. Cf. Owen, supra note 12, at 243-44 ("massive dislocations" make reallocation of frequencies (the "DuMont plan") difficult to imagine).

131. See Brown, Ferris Irks Broadcasters Over Pay TV, N.X. Times, Mar. 14, 1979, § C, at 23, col. 1 (FCC Chairman, addressing audience of television programmers, looks forward to diversification through new media).

132. According to one enthusiastic report, "cable is shattering the old mass television audience into many audiences. By 1990 , there could be as many as 20 national networks catering to as many different tastes." Smith, Television Enters the SO's, N.Y. Times, Aug. $19,1979, \S 6$ (Magazine), at 16, 18, col. 1 .

Cable television, without the scarcity limitations of broadcast television, allows each subscribing home to receive as many as thirty-five different channels. Id. Today, nearly one in five American homes with television subscribes to cable, id. at 17, col. 4 , and the cable hook-up also carries commercial-free programs (mostly movies and sports events) that are available to subscribers who pay an extra monthly fee ("pay TV"). Id.

133. See Funt, Tomorrow-'A Video Supermarket,' N.Y. Times, July 22, 1979, § 2, at 1, col. 1, 29, col. 1 (satellite distribution allows Atlanta station to build national audience on strength of sports programming).

134. See id. at 29, col. 5 (finding initial tendency toward reliance on established formats); O'Connor, supra note 3, at 1, col. 3 (finding that standard television has been expanded and made slightly more permissive). At this time, when cable still has less than $30 \%$ saturation of all American homes, programmers are concentrating on basic services for demographically desirable audiences to attract advertising to the new medium. But growth of audiences, advertising, and competition are stimulating "frenzied interest" among potential program-suppliers. Funt, supra note 133, at 1, col. 1. As the new medium grows, and programmers cautiously feel their way along, diversification will undoubtedly result; the only question is how soon it will occur. See p. 715 infra.

135. See Television Economics, supra note 16, at 90 (predicting that price competition for viewers will lessen degree of imitation and duplication by offering viewers preferred choices). 
eclipsed. ${ }^{130}$ At least one study indicates that the current societal need for regulatory reform by the FCC will persist. ${ }^{137}$ Therefore the FCC must address the economic forces inherent in national advertiser-supported, network-distributed programming. ${ }^{138}$

The objective of FCC regulation would be promotion of an efficient, competitive industry structure. Intervention would be limited to the extent necessary to make room for diversified programs that would otherwise be precluded by economic forces. ${ }^{130}$ Instead of attempting to override editorial discretion with decrees that shape content, the new policy should promote efficient editorial responsiveness to the needs of smaller audiences and to exceptional, though less popular, programs.

Based upon reliable economic data, ${ }^{140}$ the FCC could equitably regulate mass-audience program incentives exploited by the networks

136. See Funt, supra note 133, at 29, col. 6 (cable is "not a threat to any network"); Forecasters see a mixed outlook for broadcasting in the eighties, Broadcasting, Sept. 24, 1979, at 32 (new media bring "new and different people to the tube"; shares may decrease, but unit sales of broadcasting's audience can still grow).

137. A study commissioned by NBC predicted that in 1988 homes equipped with the new media will spend "no more than four or five hours a week" using them and will watch forty-seven hours of commercial television during that same week. See Future is bright for the networks, says Silverman, Broadcasting, July 30, 1979, at 28, 29.

138. Although the 1934 Communications Act confers no express authority to regulate operations of the networks themselves, the FCC has direct power over each network's five lucrative broadcasting stations. Thus, the FCC has power to discipline the networks through their licensees. FCC NETwORK Reports, supra note 53, at 105; see L. Brown, supra note 23, at 14 (FCC punished CBS licensee for network's erroneously billed "winner take all" tennis matches).

139. In the past, the FCC has recognized, and voiced disapproval of, the inevitable link between network profit-maximization and unrelenting emphasis on mass-audience programs. FCG NeTwORK REPORTs, supra note 53, at 29. More recently, an FCC study of network-affiliate relations has found that licensees are also profit-maximizers, rather than victims of network coercion, when they rely so heavily on network entertainment. Holsendolph, supra note 12. The FCC has ignored, however, courts' suggestions that it adopt a profit-related index of program service. See, e.g., National Black Media Coalition v. FCC, 589 F.2d 578, 581-82 (D.C. Cir. 1978); Citizens Communications Center v. FCC, 447 F.2d 1201, 1213 n.35 (D.C. Cir. 1971). The FCC has procrastinated in deciding a publicinterest group's petition to make licensees' annual financial reports a matter of public record. B. Cole \& M. Oetringer, Reluctant Regulators: The FCG and the Broadcast Audience 26 (1978).

140. The FCC would need to develop sophisticated economic models and accurate data. Cf. Robinson, supra note 9, at 216-24 (FCC economically naive and accepts broadcasters' self-serving data unquestioningly). Inaccuracies or distortions in the data could be minimized by establishing standardized accounting practices, cf. 47 C.F.R. pts. 31-35 (1978) (uniform systems of accounting for common carricrs), and the equity or feasibility of a proposed economic policy could then be litigated in a formal rulemaking procedure, see 5 U.S.C. $\$ 553$ (c) (1976) (each agency shall give interested persons notice and opportunity to submit data, views, or arguments); 47 C.F.R. $\$ \$ 1.411-429$ (1978) (FCC rulemaking procedure). 
and their affiliates. ${ }^{141}$ In order to alleviate the antidiversifying effects of duplicative network schedules ${ }^{142}$ and also to make room for shows aimed at specialized audiences, the Commission should require each network occasionally to forego reported ratings. ${ }^{143}$ While such a ratings suspension was in effect for the one channel in both local and national markets, there would be a ceiling on the rates at which networks-and their local affiliates-could bill advertisers for the unrated program. For example, the Commission might provide that advertisers on unrated shows can be billed no more than the average rating for a twenty-share program at that day and hour. ${ }^{144}$ Thus, the full economic benefit of a routine thirty-share program would be lost to the proprietor of the unrated channel. Because shows that do garner a thirty share or better are always relatively scarce, programmers at both the network and affiliate levels would prefer to save their more popular shows for unregulated competition. ${ }^{145}$ In this way, a special time-slot is created for broadcasting diverse shows that may be network or local, and the criterion of efficient performance, in this example a twenty share, can be adjusted by regulation as needed. ${ }^{146}$

While it is impossible to predict what types of program would be fostered under this proposal, some improvement in diversity would undoubtedly result. In the first place, economists have demonstrated that programs designed for a twenty-share audience allow more freedom for differentiation and diversification. ${ }^{14 \tau}$ Indeed, critics of television

141. This process would remain distinct from administrative ratesetting for a regulated monopoly, in that competing networks would still be able to maximize profits by operating as efficiently as possible within the regulated competitive framework. See note 149 infra.

142. See pp. 700-01 supra (sponsor preferences and strategic considerations of audience flow encourage duplication and imitation).

143. Only programs that carry no paid advertising are now exempt from ratings. Brown, Ratings Peril a TV News Form, N.Y. Times, Jan. 18, 1979, § C, at 22, col. 1.

144. See note 29 supra (difference between rating and share).

145. This would not necessarily be true in a context in which ratings were reported and compiled. Even with the regulated revenue ceiling, a network might wish to continuc competing aggressively for the mass audience to advance or defend its position in the overall ratings competition. See p. 699 supra.

146. This is an instance of appropriate regulatory intervention by the FCC, an agency established to maximize efficiency-and public welfare-in broadcasting. $C f$. Coase, The Problem of Social Cost, 3 J.L. \& Econ. 1, 17-18 (1960) (discussing how direct governmental regulation can enhance efficiency when transaction costs are too high). Conversely, the utility of television is maximized if duplicative mass-audience programming is displaced on one channel at a time by a program that attracts discretionary viewers, those members of the audience who view only programs that affirmatively stimulate their interest. $C f . \mathbf{R}$. NolL, supra note 11, at 48 (citing "strong presumption" that more diversity increases aggregate consumer satisfaction).

147. A twenty-share program need not be designed for an indifferent coalition of viewer groups; instead of falling back on common-denominator program concepts, writers 
tax it with instances of how noteworthy shows have fallen prey to the thirty-share standard of efficiency even while remaining profitable. ${ }^{148}$ Second, neither the unrated network nor its local affiliates will be able to maximize profits by simply furnishing a cheap mass-audience substitute for an expensive network show, as happened under PTAR; the competitive context is sufficiently different from PTAR to foreclose that frustrating outcome. ${ }^{149}$ Furthermore, the regulatory burden is equitably distributed among all three networks, but on a rotating basis. ${ }^{150}$

Finally, the regulated ceiling would not preclude a positive cashflow back to the network at no sacrifice of quality for the viewers. ${ }^{151}$

and producers can tailor programs to the tastes of more homogeneous groups. See p. 701 supra. In the past, network special-interest programming has drawn between $15 \%$ and $20 \%$ of the audience. $\mathrm{R}$. NolL, supra note 11 , at $\mathbf{5 2}$.

148. See, e.g., D. Halberstam, supra note 5, at 416 (condemning "merciless" quality of ratings drive that made it "not enough to succeed, to put on a good program that was sponsored and made a profit").

149. The suspension of ratings would be staggered among the networks, so that the two unaffected ones, whose programs were subject to reported national ratings, would still compete for maximum audiences and maximum ratings. Any attempt to dump weak or doubtful mass-audience material on the unrated channel will be exploited by aggressive counter-programming on the two other channels. Though habitual viewers are notoriously undiscriminating, see Smith, supra note 132, at 18, col. 3 (discussing "heavy-viewing center"), the weaker mass-audience programs are more susceptible to strong counterprogramming than are shows with a relatively small but loyal audience. Other types of low-quality mass-audience material, such as quiz or talk shows, may be popular at certain times of the day, but their conspicuous absence from prime-time network schedules in. dicates their comparative frailty in competing against strong comedy or drama with popular stars and lavish productions.

With respect to the unrated channel's strategic options, the national ratings of the two competing shows will be known to clients of the unrated station, who can negotiate a payment formula to penalize the unrated channel for failing to attract an audience commensurate in size with the regulated ceiling. Unrated programs will therefore have to address real needs and affirmative interests in order for the regulated network and its affiliates to maximize profits against conventional mass-audience competition on the other channels.

150. In a three-network model, in which viewers could desert the unrated show and go to one of the two networks carrying conventional mass-audience programs, the adverse financial impact (if any) of being periodically required to carry unrated, diversifying programs would be offset by the boost to ratings and revenues that occurred when a competing network carried unrated shows. Cf. pp. 697-98 supra (three-network rivalry discourages volunteering special-interest programs that enrich rivals).

151. The hourly cost to networks of prime-time entertainment (except for special attractions such as sports and TV-movies) falls between $\$ 400,000$ and $\$ 500,000$. See 1979-s0 Network Primetime Season At A Glance, VARIETY, Sept. 12, 1979, at 72. With thirtysecond advertising spots on an "average" show costing about $\$ 45,000$, Harmetz, supra note 26, at col. 5, the networks, which may air each one-hour program twice, make a handsome profit on every average show. Programs developed for specialized audiences can probably be made at reduced cost, given that "it is generally valid to speak of program 'popularity' . . . and cost as being highly correlated." Television Economics, supra note 16, at 96. Producers of specialty programs, in other words, can afford generous production budgets as long as they do not attempt to bid competitively for the medium's most popular 
The economic constraints might be more difficult for local affiliates who wish to produce or procure a non-network program for the unrated time-slot. Nevertheless, the availability of efficient special-interest network programs would probably preclude misguided editorial independence and protect local audiences from low-quality programs unresponsive to community needs and desires.

One issue still remains: how will the networks and affiliated broadcasters perceive-and address-the lower criterion of competitive efficiency that would be established under this proposal? Without access to adequate economic and audience-research data, the answer must remain speculative. A formal rulemaking procedure would, of course, enable the programmers themselves to come forward and give evidence. ${ }^{152}$ Notably, the founder and chairman of CBS recently proposed that each network voluntarily set aside two hours in its weekly schedule for diversified high-quality cultural or documentary programs. ${ }^{163}$ Modern audience-research techniques can certainly help networks identify the various interests that may distinguish a particular socioeconomic or ethnic minority, ${ }^{154}$ and programs designed for those interests would undoubtedly attract national advertisers who wished to target a particular group without paying for unnecessarily large numbers of extra viewers. ${ }^{155}$

This proposal will not suddenly transform network entertainment. However, it is illustrative of an economic device that the FCC could use to alleviate the mass-audience programming pressures that currently preoccupy broadcasters. Without innovative new regulation, the industry will continue to supply the same monotonous mass-audience programs. Broadcast regulation must focus on the competitive dynamics of the television industry in order to serve the public interest in diversified entertainment.

stars ("talent inputs"), who are in a position to command inflated salaries ("scarcity rents"). $I d$. Though advertising revenues will obviously be subaverage, budgetary restraints should insure that no diversifying program need incur a loss. The cheapest diversifying programs might be public affairs documentaries, which can be produced by network news department personnel who are already on the payroll.

152. Independent producers and audience representatives could also present evidence of estimated costs and audiences for different types of specialty program. See note 140 supra (all interested parties invited to participate in FCC rulemaking).

153. See W. Paley, As It Happened 275-76 (1979).

154. See Lyle, Public Broadcasting Audience \& Program Research: Problems i Possibilities, in The Future of Public Broadcasting 201, 207-08 (D. Cater \& M. Nyhan eds. 1976) (research and measurement techniques perfectly feasible for "very specific group within the population").

155. Permitting some measurement of qualitative appreciation, see note 50 supra (Q. factor), might be an additional incentive for "image" advertisers, who wish to cultivate positive recognition among a particular group of people, to support less popular shows in the unrated time-slot. 